\title{
Mary Helena Fortune: An Independent Fly IN THE Webs OF Victorian SOCIETY
}

\begin{abstract}
Mary Helena Fortune (c. 1833-1909) was a pioneer Australian crime fiction writer. At a time when marriage and domesticity still largely defined women's lives, in her autobiographical journalism Fortune freely admitted to being selffinancing. She claimed that her tea tasted better when she remembered that she has "earned every penny of the money that bought it." It was unusual for a Victorian woman. And as her memoirs and journalistic prose testify, Fortune was anything but usual. The story of her life, her writing, her husbands, sons and lovers is extraordinary, and was potentially dangerous for Fortune, given the hypocritical morals of the time. Thus, being fully aware of the webs the Victorian society set for independent flies, Fortune wrote under a pseudonym of Waif Wander which sheltered her, and protected her income. Her memoirs, partly fictionalised, a common Victorian genre, reveal an extraordinary woman and extraordinary times in Australian history.
\end{abstract}

\section{Keywords}

Australian literature; crime fiction; Victorian women; Mary Fortune; Waif Wonder; autobiographics

What has in Western culture been stabilized as autobiography, claims Leigh Gilmore, "is more accurately described as a collection of the discourses and practices individuals have used to represent themselves in relation to cultural modes of truth and identity production" (Gilmore 1994: 41). However, modes of selfrepresentation which do not reproduce dominant "ideologies of subjectivity" (41), such as those of women, have been marginalised because they could not be "interpreted/named/authorised" (42) as such. Gilmore therefore offered a term autobiographics to describe women's self-representation in writing formulating 
its four elements: "an emphasis on writing itself as constitutive of autobiographical entity, discursive contradictions in the representation of identity (rather than unity), the name as a potential site of experimentation rather than contractual sign of identity, and the effects of the gendered connection of word and body" (42). Thus, claims Gilmore, autobiographics avoids dealing with delimitations of genre and instead asks "Where is the autobiographical?" (42).

Mary Helena Fortune's autobiographical and journalistic writings offer themselves as a textbook case for the application of Gilmore's avenue of reading, as the article focuses on the mode of Fortune's memoirs.

Mary Helena Fortune was a writer of crime fiction stories for the Australian Journal, which was a trailblazer for the production of colonial literature at the time. In 1868 she initiated The Detective's Album series within which she published over 500 detective stories, until its termination in 1908. The longevity of this series exceeds that of any of the women writers elsewhere (Watson 2012: 72). When selected stories were printed in book form in 1871, it became the first detective fiction book in Australia. In addition to crime fiction, Fortune also wrote urban ethnography, romance, autobiography, Gothic serial fiction, even an occasional cooking recipe. And yet, in her lifetime, as well as for almost a century after her death, Fortune went undetected by history and the reading public. However, painstaking archival research conducted by Lucy Sussex ${ }^{1}$ in the past few decades unearthed an extraordinary life.

Mary Fortune to date remains the only Australian writer who earned her income by her pen exclusively, although according to available data, just barely. Still, her "professionalism is even more significant considering her gender. At a time when women were expected to be ... angels in the house, Fortune freely admitted to being self-supporting, without the benefit of spouse, almost unheard of for a women writing in the colonies" (Sussex 2006: 54). In her journalist piece titled "How I Spent Christmas" Fortune boasts that her tea tastes better when she remembers that she has "earned every penny of the money that bought it" (Fortune in Sussex 1989: 187).

She continues by saying that she does not "owe a single 'thank you' to one of [her] kind friends" ending this expose with an unconventional wish for a woman living in the Victorian age: "God bless ye all, my dear friends, and grant me continued independence!" (187).

Such an extraordinary person is hard to pin down for the purposes of systematic research, but Sussex comes closest to it by formulating Fortune's central characteristic: such an opinionated writer speaking directly to her readers about her life and opinions was also intensely private, shrouding her life in anonymity (Sussex 1989: xiv) and hiding under a pseudonym. Her "pseudonym shielded her - and protected her income - from her reading public, whose Victorian values she did not share" (Sussex 2006: 54). A few facts from her personal life will reveal why anonymity was imperative if Fortune was to pursue a career of a selfsupporting writer in nineteenth century Australia.

Mary Fortune was born in Ireland as Mary Wilson, and as a child emigrated with her parents to Canada. There she married Joseph Fortune in 1851, and the 
couple had a son Joseph George. In 1855, at the age of 22, she emigrated to Australia with her son to join her father, George Wilson who was then on the Victorian goldfields. As there is no evidence of divorce, and records reveal that Joseph Fortune died in Quebec in 1861 (55), and having in mind that divorce laws were strict in predominantly Catholic Quebec, Sussex concluded (60) that "Mary did a runner with the child" (55). Indicatively, she adds a comment by Sue Martin "But how brave for the period!" (55). Indeed, it was. Ironically, the boy died "of convulsions" (meningitis) three years later, aged five. In 1865 she had another child who died. Shortly after she married a police officer, a mounted trooper, stationed on the goldfields, one Percy Brett, but the couple split up soon, and again, there is no evidence of divorce, as it was a costly affair, and bigamy was common. The two had a son who also went by the name of George. Mary continued to raise her child and live in and around Melbourne for the rest of her life supporting herself by writing. However, none of this biographical information was ever revealed in her writings.

It is easy to see why in the era when "marriage and domesticity still largely defined women's lives, and they were 'expected to give birth, raise families and provide a moral, civilising influence"' (Bird in Brown 2007: 77), Fortune would hide her true identity, in spite of "her relatively high writing profile in the Australian Journal" (Brown 2014: 108). Namely, "Her claim of genteel poverty would have been hard to justify and her intimate acquaintance with the position of the fallen woman may have ended her writing career" (108).

Thus the connection between the body and writing becomes paramount for a transgressive Victorian female author. There I draw from Adrienne Rich who describes the "politics of location" in the context of self-representation: "I need to understand how a place on the map is also a place in history within which as a woman, a Jew, a lesbian, a feminist I am created and trying to create. Begin, though, not with a continent or a country or a house, but with the geography closest in - the body" (Rich 1986: 212). Rich clarifies it by saying that it means speaking "with authority as women. Not to transcend this body, but to reclaim it" (213), to write of their experiences and to write themselves into history, "refusing to let the discussion go on as before, speaking where silence had been advised and enforced, not just about our subjection, but about our active presence and practice as women" (214). It is because, "To write 'my body' plunges me into lived experience, particularity: I see scars, disfigurements, discolorations, damages, losses, as well as what pleases me" (215).

The lived experience of the body can be traced in the writings of Mary Fortune, as well as the reverse process of writing off her body that Sidonie Smith detects, thus identifying discursive contradictions in the representation of identity which characterise autobiographics:

With the caveat that I am making a vast generalization here, one that invites argument, I suggest that until recently women who wrote autobiographically, at least within the context of traditional Western autobiographical practices, had to make sure that their body had been 
neutralized before, in both senses of the word, their text. Women had to discursively consolidate themselves as subjects through pursuit of an out-of-body experience precisely because their bodies were heavily and inescapably gendered, intensely fabricated. Thus they had to write out of their bodies or write off their bodies to gain an audience at all (Smith 1994: 272).

That is to say, even if she did hide her private life from public eye, Fortune revealed a lot about herself in her writing, however, that was overlooked by conventional criticism of Fortune. Namely, conventional criticism of Fortune is twofold: there is Stephen Knight who reads Fortune's crime fiction as contributing to the dominant masculine bush tradition of late nineteenth-century Australia, because her descriptions of life on the goldfields and of nascent Australian towns mediate "between the horror of the country as seen by the convicts and the vision of sweeping profitable plains central to the squatter novels" (185). ${ }^{\text {ii }}$ For him Fortune reports of the change in perspective in description of Australia, one which is characteristic of a transition from immigrant to a colonial in her autobiographical writings. Alternatively, there is a modest corpus of feminist literary criticism led by Megan Brown which predominantly focuses on Fortune describing an interesting time in the nation's history offering a female point of view. Brown thus claims that Fortune's writing contributes to the re-formulation of the Victorian female subject (Brown 2014: 119). Namely, in a society where colonial women were expected to conform to English codes of dress and behaviour, in an environment where that was either impractical or outright impossible, Fortune's writings contributed to a change toward a womanhood which "increasingly admired the virtues of hard work, resourcefulness and practicality" (119). It is a conventional image of pioneer women who forged a "new concept of gentility which could incorporate the need for hard, physical work as pioneers' and create colonial 'discourses of womanhood' that could encompass 'bravery and adaptability" (Kathryn Gleadle in Brown 2014: 119).

While the above undoubtedly stands, it is my contention that in her autobiographical writings Fortune first and foremost reveals herself as a figure of rupture in Cixous' sense of the word, "the wild woman, the sorceress who threatens phallogocentrism with her witchy views and ways" (Gilmore 1994: 62). It is something that Sussex only opens door to, but does not take far enough, when she metaphorically writes: "the image that comes to mind is of a woman in purdah, shouting her speech from behind a brick wall" (Sussex 1989: xiv)

Thus the connection between gendered word and body that Rich talks about is revealed in Fortune's autobiographical writings. Fact is that writing in the 1880s she had no precedent, let alone a tradition of female autobiographic writing to fall back on, so she employed the forms available to her: travelogue, vignette, and short stories, all of which she could regularly contribute to a magazine since she was living off her writing.

Writers found the Australian Journal a hard paymaster. Fortune's contemporary and crime fiction collaborator, James Skipp Borlase, publicly complained that the magazine "did not pay its writers a quarter as high per page" (Sussex 
2006: 58) as the Family Herald, its English equivalent. The Australian Journal bitterly disputed these remarks. However, it was not the only magazine that paid its contributors poorly. Borlase wrote that: "Australia is, in fact, at present, the last place that the professional man or the man of letters should emigrate to. Many [are] at present enduring semi-starvation in every Australian city [because their wages] are lower than that of the compositor who sets the "copy"' (58). It is also possible that, as a woman, Fortune's pay was even more reduced. Australian journalist Alice Henry complained in 1901 that: "Women writers of more than ordinary ability receive less than half the remuneration given to men whose writing is of far inferior merit..." (58).

It is from this position of a gendered body that Fortune writes her travelogue (subsequently termed a memoir by critic Lucy Sussex) Twenty-Six Years Ago; or the Diggings from ' 55 ' which consists of six instalments and which ran from September 1882 to May 1883. This memoir and Fortune's journalism, collected and edited by Sussex, which consists of articles and stories published between 1868 and 1870, were published under the title The Fortunes of Mary Fortune in 1989 by Penguin. Since at the time Mary Fortune was an unknown writer, Sussex gives an extensive introduction wherein she establishes who Fortune is, and praises the transgressive nature of her literary output; she even terms Fortune a modern writer as she writes from the perspective of the street, and not of a Victorian salon. She gives Fortune's biography and a short summary of the texts included in the collection. Sussex then likens Fortune's journalistic writing to that of Marcus Clarke, ${ }^{3}$ but makes one immensely important distinction: "Clarke used this form for colonial commentary," while for Fortune it was "a medium for self-revelation, within limits" (Sussex 1989: xix) supporting the claim with a series of quotations from the collected texts. ${ }^{4}$ Lastly, she lists four very plausible reasons, which prevented the rediscovery of Fortune's work until the 1980s: the pseudonym, the fact that she was mostly writing crime fiction which until recently was not thought of as literature, uneven quality of her work due to her immense output, and the Australian Journal's thorough overshadowing by the Bulletin, hoping that the collection she edited would give Fortune a recognition she was denied in life.

As if the authority of the independent scholar that Lucy Sussex is was not enough to give authority to Fortune, Sussex invited Judith Brett, a professor emeritus at La Trobe, who also happens to be a great-granddaughter of Percy Brett, to write a Preface. As Judith Brett is a professor of politics, and not of literature, Brett's text is on the one hand personal - how Sussex's discovery influenced her family life, and on the other, serves to repeat, and thus corroborate Sussex's judgement of Fortune's literary value.

Sussex and Brett shape Fortune into a subject the contemporary reader would want to read about, namely the subject of a transgressive nineteenth-century genteel poor is currently en vogue. However, as far as her implied readers are concerned, Fortune established her authority with confidence. She made sure her readers knew what she has had published: 
Coming almost directly from America, and being young you know, perhaps it was natural that, in a new land and among scenes in which law was of but little account, I should bloom in the Poet's Corner as a thorough Democrat. At all events, some pieces of mine were printed in the sheet I have alluded to, of which Mr. Saint (Charles, I think) was the editor or proprietor, or both. Some of the rhymes I have alluded to I have since reprinted, but with changes that redeemed them from the Republican taint. (Fortune in Sussex 1989: 52)

Having established that even in the early days of the colony she was being published, she explains that she, or rather 'he', is so good at writing, that it has earned her a job invitation, as she was called at the newspaper's office:

The lines I write of were printed with my own initials attached, and just before I left the 'Flat' a line was addressed to me in the answer to correspondents' corner of the Mount Alexander Mail. The line was a request that 'M.H.F.' would call at this office at his earliest convenience. I was very much tickled at the personal pronoun, and curious too, so I took the opportunity of passing through Castlemaine to call at the office in question. (52)

This incident is an excellent example of effects of the gendered connection of word and body. Namely, when the editor learned that Fortune was a woman “"Are you 'M.H.F'?' he questioned with evident disbelief." (52) - the entire business deal fell through, yet she was invited to spend a "pleasant evening with $\mathrm{Mr}$ and Mrs Saint in their cottage home" (52).

Fortune's narrating I is a learned writer, somewhat of a curiosity on the Australian goldfields: she often uses expressions such as en passant, par parenthese, she refers to the Bible, English classics such as Shakespeare, Robert Burnsand Byron, as well as her American contemporary Harriet Beecher Stove. Still another characteristic which makes Fortune's text modern, and which none of her critics have mentioned, is her intrusive narrating I - she constantly passes metanarrative comments such as: "One more incident and ... I wind up this paper" (101). "Now I told you I would finish relating the circumstances connected with this sad affair... I will give them to you as I can recall them..." (117).

That Fortune's narrating I is self-reflexive about the problem of remembering we learn on the very first page of the collection as she writes that she used notes as a means of accessing memory: "I might have been afraid to trust my memory in detail had it not been for notes made at the time, which I have fortunately retained, and which greatly stimulate my recollection of my earliest colonial days" ${ }^{5}$ (3). She additionally supports the veracity of her memory by stating that "it is strange to note with what pertinacity first and new impressions will cling to the brain upon which they have been photographed" (13).

In addition to establishing herself as a competent writer, and an immigrant observing the Australian goldfields with a foreign eye, Fortune also establishes herself as a mother, as in the very first instalment she states that she is travelling by Cobb and Co. coach to the diggings with her "youngster" (14), and often writes down their conversations albeit in indirect free style. However, the most moving 
moment is her description of the family reunion on the Kangaroo Flat goldfield as she writes following a meeting with her father:

... speechless with joy, and so was I to see the dear old face I had come thousands of miles to see. He lifted out my child and held him in his arms until I stood beside him, when he peered into my face to read the record of the years. 'Thank God,' he murmured, as big drops rolled down his cheeks; and that was my welcome to the diggings. (21)

The narrating I shares all this personal information, and yet we never learn her name as she values freedom - her tea that tasted better because she earned every penny that bought it - above all, and "for women, the fiction that our names signify our true identities obscures the extent to which our names are thought of not as our own but as the legal signifier of a man's property" (Gilmore 1994: 81). This thesis is supported by Sussex who comments Fortune's pen name of Waif Wander: "Waif is a legal term, signifying among other things lack of ownership - and a woman without a legal owner in the Victorian era was single, beyond the control of husband or father. And to delve into the dictionary even further, waif also has the meaning of outcast, which for a woman in Victorian society usually meant loss of virtue" (2006: 4) suggesting that Fortune in the pseudonym hinted at her errant status. The name as a site of experimentation is yet another example of autobiographics being the appropriate reading of Fortune's texts.

Through the voice of a competent immigrant female writer and a single mother Fortune describes women's experience of living in the goldfields. While her subject choice is uncommon, the experiences she describes, and how she describes them, are not. As mentioned above, the critics commonly see Fortune providing a representative voice for a significant number of women in the colonies whose stories have been lost, and their reinstatement changes how we think about the colonial Victorian subject and the way women experienced the transition from immigrant to colonial. And indeed, Fortune does comment the grossness of kitschy wedding dresses of the newly rich ("white of the richest material ... shawl ... fastened by a huge colonial gold brooch, and festooned with a ridiculously heavy gold chain .... white bonnets wreathed with long white ostrich plumes ... rubicund face ... surrounded with a small forest of orange blossoms", 7), and their distasteful wedding ceremonies ("one of the men ... waved a sheaf of notes towards the door of the Albion ... gesticulating violently ... women were shrieking with laughter", 7) women dressed inappropriately for the climate and living conditions (woman's petticoats were caught and she "was dragged down to the rail and jammed there. Nothing saved her but her dress being turned over her head, for, see, she had slipped out of the petticoats and left them behind", 55), their cooking (her father bought the American stove, large pots and long-handle pans she could barely lift, so "the unwieldy ironmongery was never used by us, and my first essay at tart- making .... was baked over a fire in the bullock-hide chimney on a short-handled frying pan...", 46-47), furniture (calico walls, bedstead made of "mill-sawn quartering, with posts sunk into the ground ... table a couple of 
boards supported by brackets ... and seats there were none save "cases'", 23-24), cleaning of the tents, the tough lives of barmaids in grog shanties and of maid servants in Melbourne. She connects gold-digging with a lot of hard-drinking she describes the old cooking stove which was "afterwards put to illegal use" 6 (84), and describes "thousands of new and scarcely discoloured corks ... swept into an embayed bend of the creek" after a diggers' spree. Megan Brown summarizes it best:

Fortune's writing examines colonial life from the point of view of a white middle-class woman in the urban centres, rural settings and the goldfields. Her writing makes reference to documented historical events and provides anecdotal evidence of a broad range of women's experiences, which historical accounts do not always include. (Brown 2014: 109)

However, what is far more important than what she chose to write about is how she did, how she used the autobiographic form as "a medium for self-revelation," to repeat Sussex quoted above. "The sorceress," to quote Rich, ventures alone into the public space traditionally reserved for men. As such she unsettles Victorian gender identity propagated in the advice column of the very Australian Journal where the prevailing opinion was that "Marriage is undoubtedly the natural and appropriate condition of woman" (Brown 2007: 77).

Thus she describes how hard it is to travel in carts on the rough roads of the 1860s Victoria as a single woman (commenting that "Accustomed to be a thing of some little consequence as a sentient being of the weaker sex," she soon discovered that "in the eyes of carriers and their drivers, [her] comfort was not of any comparative value with the due and convenient adjustment of a loose keg or angular case", 128), how difficult it is to find lodgings in Melbourne as a single woman (in "Looking for Lodgings" she is repeatedly turned down, but the most brilliant display of irony is to be found in her response to the advertisement offering "Lodgings for a respectable female" when she comments that "By a considerable stretch of the imagination I might be considered a respectable female...", 155), and in "The Spider and the Fly" she discusses a subject she held very dearly - the issue of paid work for women. In the story she observes a job interview for a hotel housekeeper, and when the post is awarded to a pretty, yet ignorant girl, Fortune reveals that she is fully aware of the webs the Victorian society set for independent flies: "Retired we all discomfited. Retired the poor widow and her pale-faced child. What impudence she had to suppose that one without youth, and with sense, would be eligible for a position of trust under a bloated old Spider!" (229). She laughs in the face of polite society when in "Towser and Co." she takes dogs as metaphors of human character, as refers to them as "her friends of canine species" and comments "I might have said dogs once; but I am fond of fine writing, you see, and never make use of plain expressive English word when I can introduce a five or six syllabled one, expressive of nothing but my own want of common sense" (212). A few lines below she claims that as a result of this "refinement" "there isn't a woman left in the country - they are every single one of 
them ladies of the first water!" but insists that she be referred to as "a woman (not 'lady' I beg you to observe)" (216).

She is transgressive of Victorian female identity in yet another important element - her love of the bush, and freedom and egalitarianism it enables; which is the basis for Stephen Knight's claim that Fortune's writing partly rests within the Australian bush tradition. Namely, as opposed to most Victorian genteel women Fortune embraced life on the diggings. The bush, so often described by colonial women as threatening and frightening, is a place of comfort and solace for Fortune: she even describes Australian rain storm fondly and says that she does not "envy the people who doubtless rested within in comfort that stormy night - not I; but I wondered if they had ever camped out on such a night and felt it enjoyable, as I began to do" (140). She basked in the freedom that the emerging colonial society with fluid identities allowed her:

To fall asleep and dream dreams that change as quickly as the forms in an unsteady kaleidoscope, and to awaken with a bewildered feeling that you are not yourself but have changed places with some other identity, must be a sensation akin to that I have experienced when I opened my eyes in the morning after my first sleep on the diggings. (23)

Her writing makes it clear that 'old country' prejudices and the standard by which respectability was judged had to change to suit the environment. "The opportunity to live outside the social boundaries, to be free of domesticity, to be part of a family structure that makes no unreasonable demands on her and to be so close to the natural world gives her a sense of freedom that she hints is unique to this time and place" (Brown 2014: 115). More importantly, she celebrates the change towards a more egalitarian society as the bush and the goldfields provide pleasure and a sense of community that transcend class. Community was important because, as Fortune pointed out, "[a]lmost everybody took an interest in their neighbours in those days, as upon them depended the comfort and quiet of one's lives" (112). If there was trouble, people responded immediately: "[a]s if a blow upon a hive had alarmed the busy tenants at his shout, every man and woman emerged from tent and dwelling, running" (112).

And while she could understand the fear before the unknown that women felt immediately upon their arrival, which also prompted her musings on her move:

I began to realise that I was on the borders of a new life. All the perils of the sea were over, and it lay an impassable barrier between me and the old happy Canadian life. What fate was to be for me and mine in this land of gold over which the shadows of night were slowly dropping? Could the question have been answered, would I have stopped and retraced my steps? Alas! It is impossible to say, for human nature is a strange thing, and the unknown and untried has always attractions for the sanguine and the young. (19-20)

She could definitely not understand the women who refused to make the transition from an immigrant to a colonial and perpetually complained about their 
decision thus making their lives, as well as the lives of those around them, miserable:

\footnotetext{
'You astonish me!' I cried, and indeed, truthfully. 'You are as young as I am and, I hope, healthy; you have your husband and the dearest little girl; how can you feel anything unpleasant in your surroundings? As for myself, I do think I never was happier in my life!' (111)
}

Megan Brown appropriately detected that "For Fortune the construction of colonial womanhood is dependent on the ability to change and adapt" (Brown 2014: 109). As she looks back at her " stirring, hardy and eventful life on the early goldfields' ('Twenty-Six Years Ago', September 1882, 33), she writes proudly about the obstacles that she, and the colony, have faced and overcome" (109).

The transition is especially hard on the mothers writes Fortune who upon arrival are "mostly a bewildered, half-lost expression in their anxious faces" (19), because "a woman, especially with little ones in charge, can scarcely be expected to feel safe or comfortable in a strange land, and among a class of people she has been told were as rough and knobby as the stones from among which they were rooting out their gold" (18).

Demands that the emerging settler society placed on mothering meant that mothers needed to be judged by new standards. While Fortune conforms to the Victorian ideal of motherhood where is refers to the commitment to the child and its wellbeing, she refuses to see motherhood within marriage as a duty to the state, and rejected its connections with domesticity.

Thus Fortune is particularly bitter towards mothers who gave up on their children as there is evidence that she stuck by her son through all his troubles, ${ }^{7}$ to the extent that she eventually ended up as an inmate "of the Melbourne Home" (Sussex 2006: 56). That would have been the Melbourne's Immigrants Home two years previously described by Marcus Clarke as a "terrible Golgotha of ruined lives" (Sussex 2010: 139), which meant that she was homeless, and yet she was still publishing regularly for the Australian Journal.

A few years later the editor of the Journal said that Fortune was "of bibulous habits, for which, God knows, she probably had every reason, as she wrote more, and doubtless got less for it, than any other Australian writer of the time" (Sussex 2006: 58). In 1874 the Police Gazette of Victoria noted:

Information is required by the Russell-street police respecting Mary Fortune, who is a reluctant witness in a case of rape. Description: -40 years of age, tall, pale complexion, thin build; wore dark jacket and skirt, black hat, and old elastic-side boots. Is much given to drink and has been locked up several times for drunkenness. Is a literary subscriber to several of the Melbourne newspapers. Stated she resided with a man named Rutherford, in Easy [Easey] Street, Collingwood. (10 February 1874: 10)" (59)

The extent to which it troubled her is best exemplified in a series of drunken mothers the narrating I meets. For Fortune, this instance of giving up is as much 
a matter of refusing to make a transition from an immigrant to a colonial, which she disapproves, as it is a matter of mothers being expected to fulfil their duty towards their children, to protect them, and not to abandon them. In "Inkerman" Mrs Deasy, ${ }^{8}$ desperate in the, as yet only nascent, society on the gold-diggings, quickly succumbed to the influence of dubious woman on the goldfields, the narrator seeing her

staggering back to her tent to sleep off the immediate effects of the drink she was ruining herself for, or being led there by her pretended friend Bella. At such times she would take the poor little child with her, or leave her on the grass playing with her faithful pet, and once she came to me, led by my little boy, who said that she was asleep on the grass, and awoke crying for her daddy, but there was no one in the tent. (120-121)

The child ultimately drowns, with the father coming home to uncover the horror: "She has crawled out under the tent, and is gone, while her wretched mother is lying drunk in bed!" (123). Fortune not only describes her in terms a "red, bloated face", "look of disorder that hangs round and betrays the woman who drinks," and of her "idiotic stupidity" (124), but curses her, too, as child's father shouts: "May the great curse of a just God follow you to the deathbed of a drunkard" (124). Fortune makes a point that there was not "one hand extended to help [the woman] up, not even that of the wicked woman who had helped her to make herself the murderess she, in the sight of Heaven, undoubtedly was" (124).

In another instance of maternal transgression, of a mother leaving her husband to run away with another man, Fortune refers to the child as "dishonoured" (64), and does not pity the woman despite her subsequent misery. Her wretchedness is formulated as poetic justice: "But how could I pity her - I, who had seen her husband when he went home rejoicing, to find a disgraced home..." (66).

However, Fortune is very apologetic of poor mothering resulting from loss of sanity caused by domestic abuse, a topic not normally discussed in literature of the day.

Namely, in "Chinaman's Flat" the narrator encounters a young woman, Ann Rashborne, with a baby in her arms, "standing on the very brink of the water, and in so dangerous a position that [she] involuntarily seized her by the skirts and dragged her back" (81). Ann's chilling "Are you going to tell?" makes the narrator continue to observe this woman with appalled sympathy, even when learning that "the poor crathur's quite gone in her head" (83) and set on killing her own child ("'Killing her own child!' I repeated with horror", 83). Even when Ann ultimately did "throttle the baby all out" (88), Fortune shows understanding for her ending the story of Ann by mentioning the "strange stories of the ill-treatment" Ann had received from her husband and her mother-in-law during her married life, stating that those "laid her insanity and its sad consequences at their door" (88).

Transgressive in relation to Victorian propriety this perceptive, well-read, intelligent woman, astonishingly skilled writer in the early days of Australia not only lived and died in complete obscurity, ${ }^{9}$ but had to wait over a century for her 
work to be discovered, appropriately attributed to her, and reappraised. Thus at this moment when we look at the author in relation to dominant discourses of power, autobiographical texts become autobiographics, and the naive assumption that autobiography tells universal truth, is "radically particularised by a ... culture's notion of what truth is, who may tell it, and who is authorised to judge it" (Gilmore 1994: 107).

Mary Helena Fortune continued to write into old age. Fortune's letter to her friend Minaille Furlong in June 1909 (Sussex 2010: 197) reveals that she was impoverished and blind, and suffering from senile dementia: "there is a want in that brain somewhere nothing else can possibly account for the muddle" (140). The Australian Journal granted her annuity, thus ending her independence, but she was unable to work anymore. The Journal even paid "'for her burial in another person's grave' - a chilling detail that, like much in her life, evades explanation" (141).

Thus the following quote from Cixous describes Fortune best: "It is no accident: women take after birds and robbers just as robbers take after women and birds. They [illes] go by, fly the coop, take pleasure in jumbling the order of space in disorienting it, breaking them all up, emptying structures, and turning propriety upside down" (Cixous 1976: 887). However, everything comes at a price.

\section{Notes}

1 It was a book collector, J.K. Moir, who embarked on a search for a Waif Wander in 1950s, at the time when people who knew her were still living. He located a few manuscript poems, and a letter dated in 1909 signed by M.H. Fortune. If it had not been for him Fortune's name might never have been revealed. Sussex picked up on Moir's research.

$2 \quad$ Knight builds his argument by describing how Fortune contributed to two of the four elements of crime fiction which he detected "derived and developed in this county with specific local meaning" (Knight 1997: 174): zero policing and the goldfields tradition. Decades before Lawson, Patterson and the fellows of the Dawn and Dusk Club of the revivalist 1890s Fortune, introduced new and positive interpretations of Australian topography thus formulating what T. Inglis Moore put a name to in his Social Patterns in Australian Literature: the spell of the bush. Fortune also detected and was one of the first to describe the salvaging of a miner from the sinking hole, the event which looms large in the Australian psyche, as well as archetypal Australian fears - that of the dead man in the bush, and that of hatters in the bush, all of which were common topoi of the dominant Australian nationalist literature of the 1890s.

3 Who had been her editor for two years "but there is no evidence she was part of his freewheeling fraternity" which met socially at the famous Yorrick Club, as it was for men only (Sussex xxi).

$4 \quad$ Sussex gives examples of Fortune's son never seeing a ship which is described in "How I Spent Christmas" as well as a mention of pantomime posters around Melbourne at the time when Fortune's own pantomime Harlequin Little Bo Peep played in Sydney, of Fortune describing herself as an "honest, downright, straightforward" woman who protested the ideal of "dependent and helpless femininity" in "Towzer \& Co." (Sussex 1989: xx), while "The Spider and the Fly [...] may describe an actual job interview" (Sussex 1989: xxi).

5 She was to write a series of articles for English magazine titled Ladies' Companion, but the engagement since fell through as the pay was very small. English magazines of the day were full of stories from the goldfields. 
$6 \quad$ "The illegal uses of a stove are limited; it most likely became part of a still. Whether Fortune and her father actually made moonshine is unknown, but she describes such activity in her fiction with her usual unwomanly authority: 'The still, although of rough formation, was in complete working order. The boiler stood over the hot ashes, among which still remained red embers, and the head and worm were attached; and the worm carried its convolutions down through a large hogshead of cold water, discharging the "mountain dew" by a pipe near the bottom into a vessel for the purpose' ('Jim Dickson's Fit of the Horrors', 333)" (Sussex 2010: 136).

7 Eastbourne Vaudrey Fortune was known as George Fortune, Henry Lidney and under various other aliases. "He served over twenty years in Victorian prisons for offences ranging from vagrancy to robbery under arms." (Sussex 2006: 55). He was first arrested as a teenager; he was found to be "neglected child," which meant that he was on the streets unsupervised, and was sent to an institution. Even though the child was in the Children's Registers of State Wards described as clean and literate, and even though Fortune came to bail him out, he was still committed to the Industrial School (Reform School) for two years, which was common for children considered to be at risk. Fortune did not give up, she kept writing the authorities, and a discharge was finally approved "but something happened," (Sussex 2006: 56) and E.V. remained in the School. In 1872 he absconded with three other boys, but was caught for stealing tobacco and re-committed. From then on, until 1890 his life consisted of further absconding and petty thefts, when in 1890 he was sentenced to ten years hard labour for burglary, his last sentence. "Perhaps at this point another image from Victorian genre painting should be added to the Fortune display: the suffering mother, true to her offspring despite adversity" (Sussex 2006: 56).

8 It is indicative that she still protects her good name and in a metanarrative comment writes: I find I have not yet given her or him a name, [she had - Clark] but as I have a good deal now to say about them I may call her Mrs Deasy" (Fortune in Sussex 1989: 120). There was not even an obituary in the Australian Journal to mark the end of her literary career (Sussex 1989: xiii).

\section{References}

Brown, Megan (2007) I shall tell just such stories as I please: Mary Fortune and the Australian Journal. Australian Literary Studies 23 (2), 74-88.

Brown, Megan (2014) A Literary Fortune. In: Maggie Tonki, Mandy Treagus, Madeleine Seys, Sharon Crozier-De Rosa (eds.) Changing the Victorian Subject. Adelaide: University of Adelaide Press, 105-122.

Cixous, Helene (1976) The Laugh of the Medusa. Signs 1 (4), 875-893, translated by Keith Cohen and Paula Cohen.

Gilmore, Leigh (1994) Autobiographics. Ithaca, N.Y.: Cornell University Press.

Knight, Stephen (1997) Continent of Mystery. Carlton: Melbourne University Press.

Rich, Adrienne (1986) Notes toward a Politics of Location. In: Adriene Rich: Blood, Bread and Poetry. New York: Norton, 210-231.

Smith, Sidonie (1994) Identity's Body. In: Ashley, Kathleen, Leigh Gilmore and Gerald Peters (eds.) Autobiography and Postmodernism. Boston: University of Massachusetts Press Amherst, 266-292.

Sussex, Lucy (2006) Mary Fortune: The Only Truly Bohemian Lady Writer Who Has Ever Learned a Living by Her Pen in Australia. Overland, 183, 54-60.

Sussex, Lucy (ed.) (1989) The Fortunes of Mary Fortune. London: Penguin Books.

Sussex, Lucy (2010) Women Writers and Detectives in Nineteenth-Century Crime Fiction. London: Palgrave Macmillan. 
Watson, Kate (1984) Women Writing Crime Fiction, 1860-1880, Fourteen American, British and Australian Authors. Jefferson, NC and London: McFarland \& Company, Inc., Publishers.

TiHANA KlePaČ is assistant professor at the Department of English, Faculty of Humanities and Social Sciences, University of Zagreb where she teaches nineteenth-century Australian literature. She has published papers on Australian exploration narratives and early Australian women's writing. She has co-edited Irish Mirror for Croatian Literature: Theoretical Assumptions, Literary Comparisons, Reception with Ljiljana Ina Gjurgjan (2007), and English Studies from Archives to Prospects with Stipe Grgas and Martina Domines Veliki (2016). Her research interests include nineteenth-century white settler literature of Australia, and women's life writing.

Address: Dr. Tihana Klepač, Department of English, Faculty of Humanities and Social Sciences University of Zagreb, Croatia. [email: tklepac@ffzg.hr] 